\title{
ROLA DZIALAŃ PROEKOLOGICZNYCH W KSZTAŁTOWANIU ŚWIADOMOŚCI EKOLOGICZNEJ
}

Streszczenie: Poziom świadomości w zakresie ochrony środowiska wśród studentów nie jest wystarczający. Mimo że opisywane badania przeprowadzone zostały w odstępie 11 lat, nie zmienił się on w stopniu oczekiwanym, a w niektórych obszarach nastąpił nawet spadek podejmowanych działań proekologicznych. Podnoszenie poziomu świadomości ekologicznej i kształtowanie postaw możliwe jest tylko w toku edukacji ekologicznej i obszernego informowania na temat stanu i potrzeb środowiska oraz działań prośrodowiskowych prowadzonych w najbliższym i dalszym otoczeniu. Stan wiedzy studentów wskazuje na konieczność podjęcia natychmiastowych kroków, by wpłynąć na zasób informacji będących bazą do rozpoczęcia kształtowania świadomości prośrodowiskowej. Świadoma ekologicznie jednostka będzie w codziennym życiu działała w sposób przyjazny dla środowiska i dokonywała wyborów, które nie będą środowisku szkodziły. Przedstawione wyniki badań wskazują na konieczność intensywnej edukacji ekologicznej oraz weryfikacji skuteczności działań różnych instytucji w tym zakresie.

Słowa kluczowe: świadomość proekologiczna, edukacja ekologiczna

Z perspektywy początków obecnego stulecia wyraźnie widać zmiany, jakie dokonały się w ostatnich latach. Każde pokolenie ma do rozwiązania nowe problemy, ale też może cieszyć się z osiągnięć, które wpływają na podnoszenie komfortu życia. Od wielu lat świat zastanawia się, jak pogodzić dążenie do rozwoju cywilizacji z podejmowaniem działań prośrodowiskowych. Czy jest to w ogóle możliwe? Jedna z zasad Deklaracji z Rio w sprawie środowiska i rozwoju zwraca uwagę, że do osiągnięcia trwałego i zrównoważonego rozwoju konieczne jest, aby ochrona środowiska stanowiła nierozłączną część procesów rozwojowych i nie była rozpatrywana oddzielnie. Działania podejmowane przez badaczy, naukowców i nauczycieli powinny iść w kierunku przygotowania kolejnych pokoleń do rozwiązywania problemów dnia codziennego oraz do sprostania wyzwaniom środowiska.

Działania prośrodowiskowe mają sens tylko wtedy, gdy będą budzić wrażliwość ekologiczną uaktywniającą środowisko szkolne i lokalne. Zadaniem edukacji ekologicznej jest aktywizacja społeczeństwa i motywowanie go do działań 
proekologicznych. Działania edukacyjne podejmowane w poszczególnych obszarach kraju można podzielić na:

- gminne,

- regionalne,

- wojewódzkie,

- ogólnopolskie.

Dla społeczeństwa ważna jest kampania informacyjna. O działaniach prośrodowiskowych powinno się dużo mówić. Zanim powstanie potrzeba ich podejmowania, muszą bowiem nastąpić przyswojenie tej tematyki i akceptacja planowanych przedsięwzięć.

Edukacja środowiskowa powinna zmierzać do ścisłego powiązania nauczania z otaczającą rzeczywistością, skupiać się na problemach środowiska, które wynikają z potrzeb określonych grup ludzi, a następnie analizować te problemy i w końcu zajmować stanowisko międzydyscyplinarne i globalne (Cichy 2003).

Jesteśmy przeświadczeni, że działania podejmowane w celu podniesienia świadomości prośrodowiskowej odgrywają ważną rolę w edukowaniu społeczeństwa. Świadomość ekologiczna może być rozpatrywana w znaczeniu wąskim, czyli jako wiedza, poglądy i wyobrażenia o środowisku. Znaczenie szersze dokłada do tej wiedzy postawy prośrodowiskowe, idee, wartości i opinie o środowisku (Domka 1998).

Rok 1997 przyniósł ważne zmiany w postrzeganiu tematyki proekologicznej, ponieważ do Konstytucji RP wprowadzono zasady zrównoważonego rozwoju, co powiązało rozwój gospodarczy i wzrost stopy życiowej z poprawą stanu środowiska. Nowy porządek konstytucyjny wymagał opracowania nowej polityki ekologicznej państwa, uwzględniającej udział społeczeństwa w działaniach na rzecz ochrony środowiska. Głównym jej celem jest podnoszenie świadomości ekologicznej społeczeństwa, zgodnie z zasadą „myśl globalnie, działaj lokalnie”, prowadzącą do:

- proekologicznych zachowań konsumenckich,

- prośrodowiskowych nawyków i pobudzenia odpowiedzialności za stan środowiska,

- organizowania akcji lokalnych służących ochronie środowiska,

- uczestniczenia w procedurach prawnych i kontrolnych dotyczących ochrony środowiska (Ministerstwo Ochrony Środowiska 2008).

Głównym celem nowej polityki ekologicznej państwa jest zapewnienie bezpieczeństwa ekologicznego społeczeństwu polskiemu w XXI wieku oraz stworzenie podstaw dla opracowania i realizacji strategii zrównoważonego rozwoju kraju. W tym celu Rada Ministrów stworzyła Strategię zrównoważonego rozwoju Polski do roku 2025.

W opracowaniu podjęto próbę oceny działań podejmowanych przez różne instytucje w celu podniesienia świadomości ekologicznej. Dla pełniejszego zobrazowania tej problematyki w pierwszym kwartale 2016 roku przeprowadzono ankietę wśród studentów dwóch uczelni warszawskich i uczelni w Płocku na wydziałach pedagogiki. Przygotowując badanie i opracowując narzędzia, posłużono 
się ankietą, którą przeprowadzono 11 lat temu w trzech warszawskich uczelniach, lecz z powodu mało interesujących wyników wcześniej zaniechano jej opracowania.

Teraz odszukane dane tej ankiety pozwoliły na skonstruowanie nowego kwestionariusza, zawierającego podobne pytania, by wyniki były porównywalne. Po tak wielu latach nie wszystkie pytania można było zadać, ale znaczna ich część pozostała w niezmienionej postaci.

W badaniu uczestniczyło łącznie 1709 osób z wydziałów pedagogicznych. W roku 2005 było to 923 studentów ze specjalności edukacja wczesnoszkolna i pedagogika przedszkolna oraz pedagogika resocjalizacyjna, a w roku 2016 - 786 studentów ze specjalności edukacja wczesnoszkolna z pedagogiką przedszkolną, pedagogika resocjalizacyjna oraz bezpieczeństwo wewnętrzne. Najliczniej w badanej grupie reprezentowani byli studenci pedagogiki ze specjalnością edukacja wczesnoszkolna i pedagogiki przedszkolnej.

Ankieta była anonimowa. Kwestionariusz z 2005 roku zawierał 18 pytań, z czego 5 było otwartych. W 2016 roku pominięto pytania, na które ze względu na postępującą reformę oświaty nie dało się już udzielić odpowiedzi. Pytań było 15, z czego 3 otwarte.

Wykres 1. Źródła informacji o działaniach prośrodowiskowych

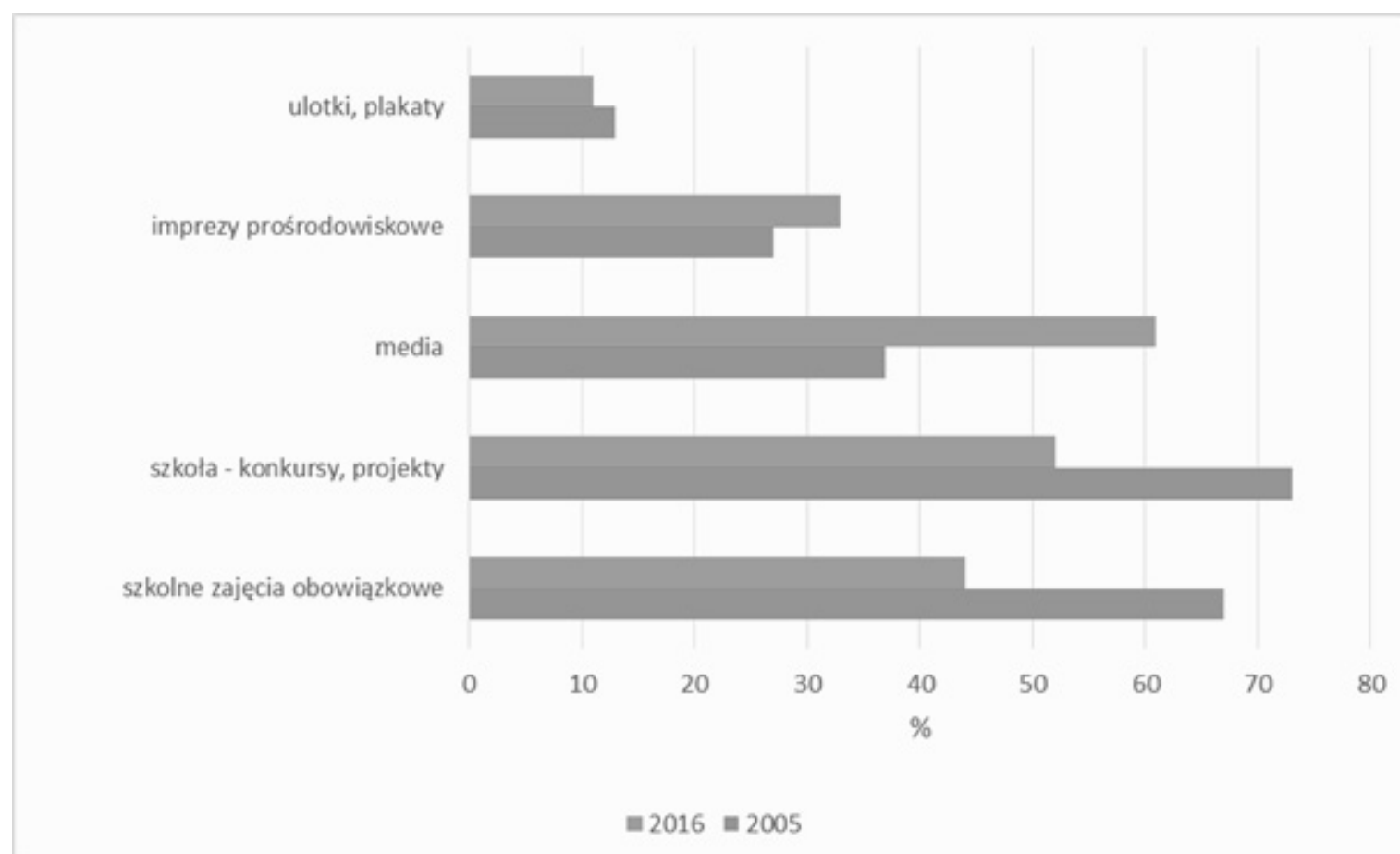

Źródło: badania własne.

Studenci mieli możliwość podania definicji ekologii i zrównoważonego rozwoju. Ekologia zdaniem badanych łączy się z ochroną środowiska i zdrowym odżywianiem. Takiej odpowiedzi udzieliło $67 \%$ badanych, a tylko $12 \%$ odpowiedziało 
prawidłowo. Brak odpowiedzi zanotowano u $3 \%$ badanych. Termin „rozwój zrównoważony" znany jest $72 \%$ respondentów, ale już jego zdefiniowanie nastręcza dużych problemów. Tylko niecałe 11\% zrobiło to prawidłowo. Co trzeci badany, definiując rozwój zrównoważony, częściowo wskazał elementy prawidłowe. Ponad 50\% nie umiało, niestety, wypełnić treścią definicji tego terminu.

Kolejnym zadaniem było określenie źródeł pozyskiwania informacji na temat prośrodowiskowych działań i problemów środowiska przyrodniczego. Wyniki okazały się bardzo interesujące. W badaniach (wykres 1.) przeprowadzonych w tym roku co drugi student (50\%) wskazał jako źródło informacji o działaniach prośrodowiskowych, które są podejmowane w Polsce, w tym w najbliższej okolicy, zajęcia lekcyjne. W roku 2005 zajęcia szkolne były miejscem poznawania tematyki prośrodowiskowej dla 67\% respondentów. Jeżeli chodzi o ścieżkę ekologiczną, to treści proekologiczne pojawiały się według badanych prawie na wszystkich przedmiotach. W roku 2016 wskazano głównie na przyrodę w szkole podstawowej i biologię w gimnazjum. Niewielki odsetek (poniżej 4\%) badanych za miejsce realizacji treści prośrodowiskowych uznał szkołę ponadgimnazjalną. Badania sprzed lat przypomniały ścieżki międzyprzedmiotowe i obowiązek ich realizacji od 1 września 1999 roku na podstawie dokumentu Podstawa programowa ksztatcenia ogólnego. Decyzje o sposobie realizacji ścieżek edukacyjnych podejmował zespół nauczycieli, którzy mieli współdziałać na rzecz tworzenia w świadomości uczniów zintegrowanego systemu wiedzy, umiejętności i postaw. Każdy nauczyciel wskazywał te ścieżki i treści, które może uwzględnić w swoim programie nauczania. Realizacja ścieżek przedmiotowych była kontrolowana przez nadzór pedagogiczny, więc pomijając kwestię zaangażowania nauczycieli różnych przedmiotów, i tak wszyscy uwzględniali tę problematykę na swoich zajęciach.

Pamiętamy wielką krytykę ścieżek międzyprzedmiotowych, co wykazały badania na ten temat $\mathrm{z} 2007$ roku (www.lider.szs.pl). W ocenie nauczycieli przynosiły one małe efekty. Tylko 31,3\% nauczycieli z Warszawy i 47\% z Radomia potwierdziło zadowalającą efektywność realizowanych ścieżek edukacyjnych. W opinii ponad połowy nauczycieli obu miast dyrekcja nie uznawała ich za ważne zadania w szkole. Występowały także duże różnice w liczbie godzin przeznaczonych na realizację ścieżek przedmiotowych. Ponad dwukrotnie więcej w semestrze było ich w Radomiu niż w Warszawie. To były powody dużej krytyki ścieżek międzyprzedmiotowych.

Wśród młodzieży największą aprobatą cieszyła się edukacja prozdrowotna. W drugiej kolejności w Warszawie była edukacja ekologiczna, w Radomiu znalazła się ona na trzecim miejscu. Większość (95\%) pedagogów uznało, że tematyka ścieżek w nauczaniu jest potrzebna, mimo krytyki ich organizacji i braku godzin na realizację tej tematyki. Tylko $5 \%$ uznało ją za zbędną. $Z$ bieżących badań wynika, że obecnie wiedza zdobyta na zajęciach szkolnych jest niewystarczająca i dużo mniejsza niż u studentów sprzed lat. A ta wyniesiona z zajęć pozalekcyjnych nie dotyczy ogółu uczniów. W roku 2005 ponad $70 \%$ badanych wskazało na udział w dodatkowych konkursach i projektach, podkreślając motywującą rolę nauczyciela. Rok 
2016 cechuje natomiast deklarowana przez studentów autonomia w podejmowaniu decyzji w sprawie udziału w zajęciach pozalekcyjnych, konkursach i projektach. Niewiele ponad 50\% wskazało, że źródłem pozyskiwania wiadomości z zakresu ekologii i przyrody są działania podejmowane dobrowolnie przez uczniów. W badaniach z bieżącego roku wzrosło natomiast znaczenie mediów oraz imprez, festynów i happeningów prośrodowiskowych.

Studenci wskazywali też czynniki mające wpływ na poprawę środowiska naturalnego (wykres 2.). Zdaniem respondentów z badań w 2005 roku istotne znaczenie miała kondycja finansowa państwa, ważne było także zainteresowanie państwa problemami środowiskowymi, aktywność władz lokalnych oraz edukacja ekologiczna społeczeństwa. Wszystkie te czynniki ulokowały się w przedziale $43-67 \%$.

Wykres 2. Czynniki mające wpływ na poprawę stanu środowiska naturalnego

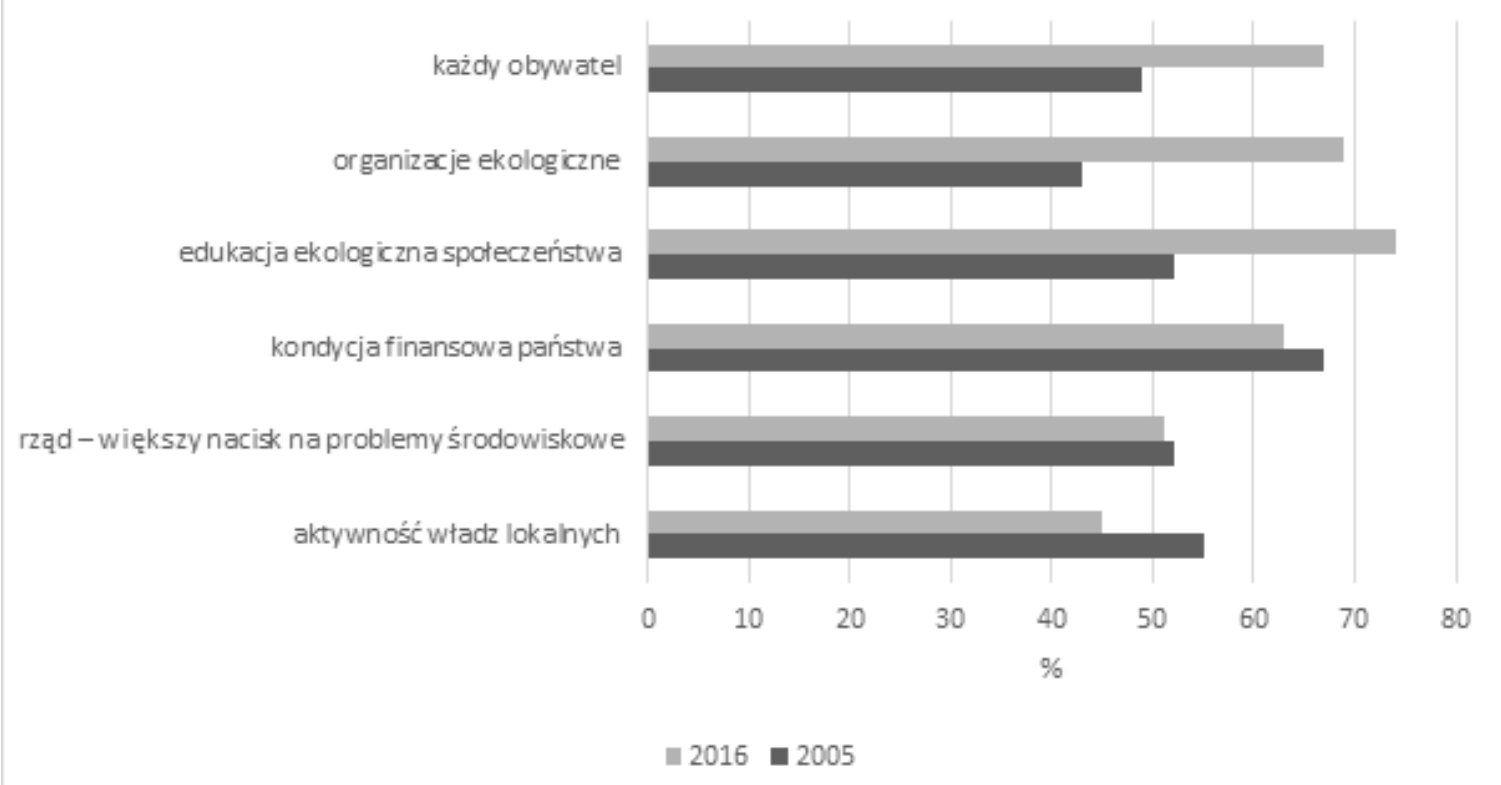

Źródło: badania własne.

W badaniach z 2016 roku trzech na czterech respondentów (74\%) wskazało na znaczenie edukacji ekologicznej społeczeństwa. Zdecydowanie wzrosła rola organizacji ekologicznych (69\%) i działań podejmowanych przez każdego obywatela (67\%). Zmieniło się podejście do możliwości poprawy środowiska naturalnego, zmalało znaczenie działań organizowanych przez instytucje państwowe i samorządowe na korzyść pozaformalnych. 
Wykres 3. Działania kształtujące świadomość proekologiczną

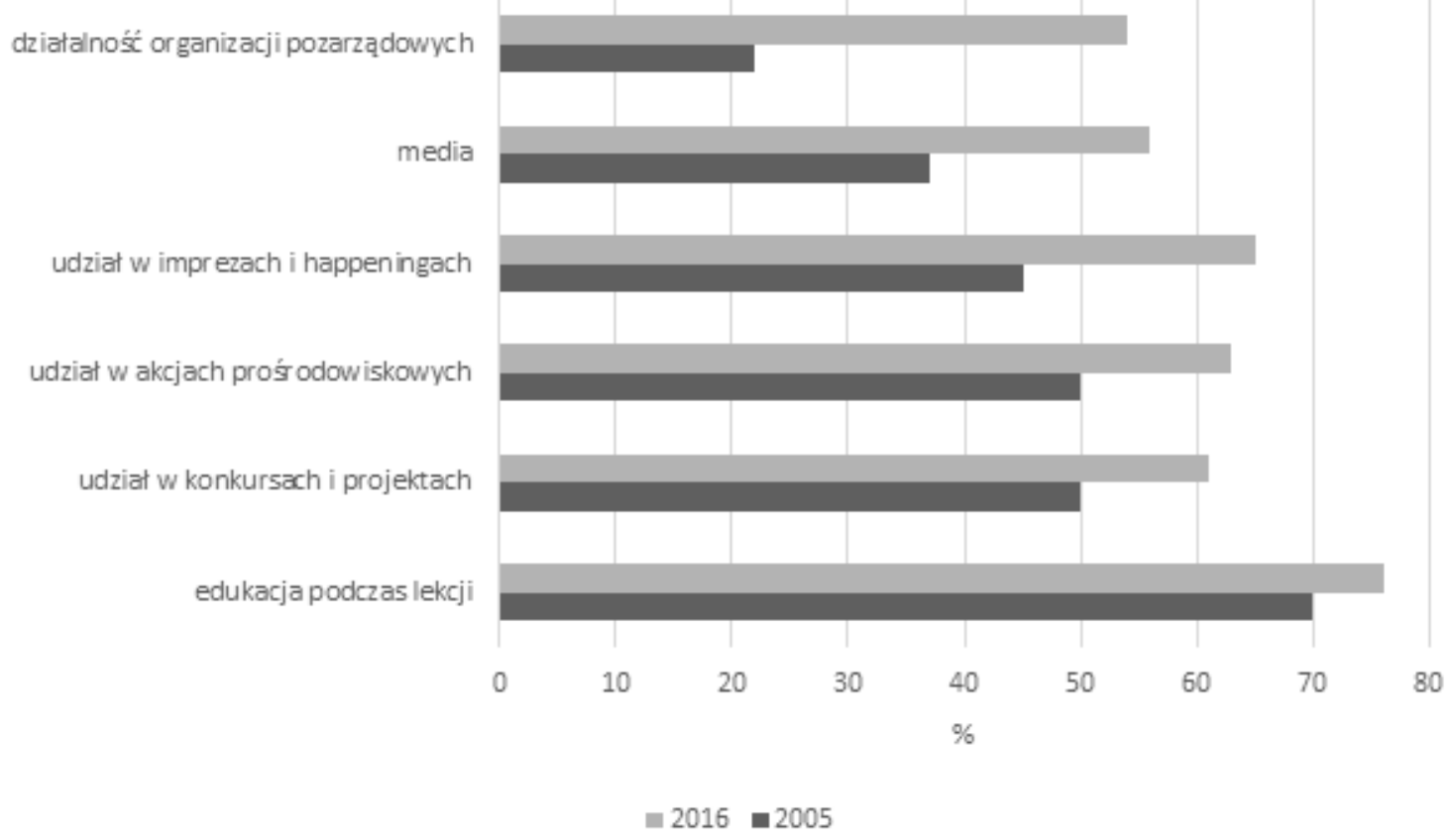

Źródło: badania własne.

Respondenci wskazywali działania, które ich zdaniem najskuteczniej wpływają na kształtowanie świadomości prośrodowiskowej (wykres 3.). Wszystkie one w badaniach z roku 2016 otrzymały wskazania w zakresie od 54 do $76 \%$ i ich rola była zdecydowanie większa niż w sondażu sprzed 11 lat.

W obu badaniach respondenci zauważyli znaczenie zajęć lekcyjnych w kształtowaniu świadomości ekologicznej $(2005=70 \%$ i $2016=76 \%)$ oraz udziału w konkursach i projektach. Po latach wyraźnie wzrosła rola działalności organizacji pozarządowych (o ponad 30\%), mediów oraz różnych akcji i imprez prośrodowiskowych.

Jednymi z najważniejszych instytucji podejmujących, realizujących i promujących działania z zakresu ekologii i ochrony środowiska są szkoły. Wszyscy respondenci podkreślają rolę placówek oświatowych, chociaż praktyczna wiedza wynoszona ze szkoły jest dość skromna. Badania wskazują na istotę różnych działań podejmujących tematykę proekologiczną w kształtowaniu świadomości prośrodowiskowej. W przekonaniu studentów zyskują na znaczeniu działania pozaformalne, umożliwiające udział poszczególnych jednostek, co samo w sobie świadczy o zmianie świadomości proekologicznej społeczeństwa.

Respondenci mieli też możliwość wskazania działań proekologicznych podejmowanych w życiu codziennym (wykres 4.). W roku 2005 jako najistotniejsze studenci wskazali: ograniczenie zużycia energii, segregowanie odpadów, zmniejszenie liczby plastikowych toreb, używanie biodegradowalnych proszków do prania, 
ograniczenie zużycia gazu. Rok 2016 przyniósł inne spojrzenie na omawiany problem. Studenci bardziej szczegółowo określali działania podejmowane w celu ochrony środowiska. Najczęściej wymieniane były: segregacja śmieci, stosowanie energooszczędnych żarówek i sprzętu oraz wyłączanie trybu czuwania w urządzeniach (stand by), używanie toreb wielokrotnego użytku nadających się do recyklingu, ograniczenie zużycia wody. Mimo innego spojrzenia i upływu czasu katalog podejmowanych działań w zasadzie się nie zmienił. Aby jednak porównać dane z obu okresów, przyjęto ograniczenie zużycia energii z 2005 roku jako odpowiednik szczegółowych czynności wpływających na zmniejszenie zużycia energii (energooszczędność) z 2016 roku. W 2005 roku studenci wskazali także na konieczność ograniczenia zużycia plastikowych toreb, w danych z 2016 roku będziemy ich porównywać z liczbą zwolenników używania toreb wielokrotnego użytku. W 2016 respondenci nie wymienili ograniczenia zużycia środków chemicznych w gospodarstwie domowym jako działania podejmowanego w codziennym życiu. Wśród pierwszych pięciu wskazań pojawiają się także oszczędność zużycia gazu (2005 rok) i wody (2016 rok), ale dane te nie mogą być porównywane.

Wykres 4. Działania prośrodowiskowe podejmowane w życiu codziennym

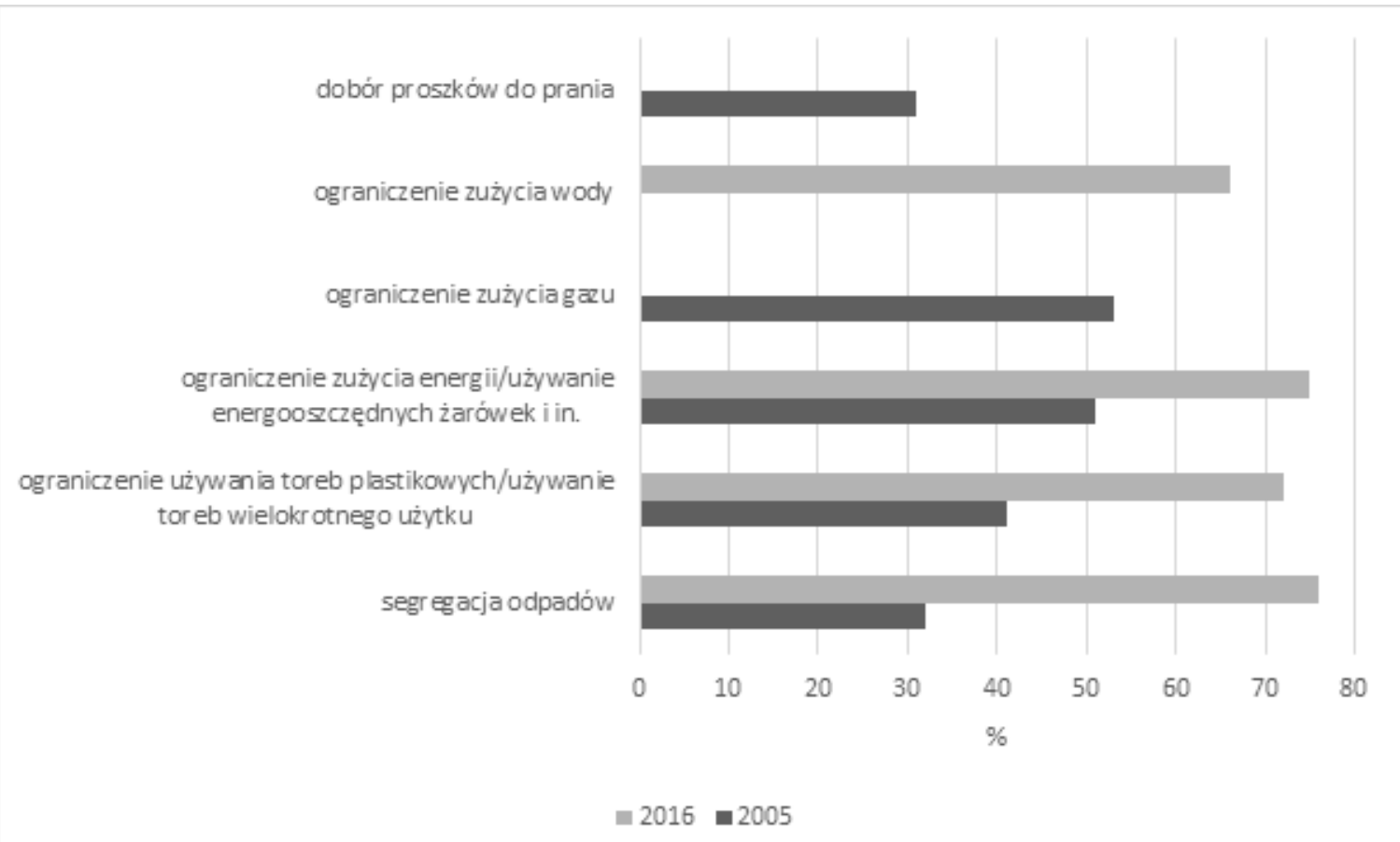

Źródło: badania własne.

Analiza danych wskazuje na zmianę deklarowanych działań towarzyszących codziennym zachowaniom. Uwzględniając najczęściej wymieniane działania, trzy są warte omówienia. W 2005 roku 51\% respondentów deklarowało, że oszczędza energię w swoich domach. W 2016 roku studenci także wskazali zachowania związane $\mathrm{z}$ oszczędnością energii, ale zwrócili uwagę na konkretne działania z tego 
zakresu. Do porównania użyto średniej arytmetycznej z liczby szczegółowych wskazań (wykres 5.). Bieżące badania pokazały wielką zmianę deklarowanych zachowań. Aż 86\% osób wskazało na używanie energooszczędnych żarówek, a 71\% zadeklarowało, że używa energooszczędnych urządzeń. Co trzeci badany (69\%) uważa, że istotnym działaniem jest wyłączanie odbiorników z gniazdka, aby nie czerpały prądu w trybie czuwania. Uogólniając, można stwierdzić, że nastąpił wyraźny wzrost liczby studentów deklarujących ograniczenie zużycia energii.

Wykres 5. Konkretne działania podejmowane przez respondentów z zakresu ograniczenia zużycia energii

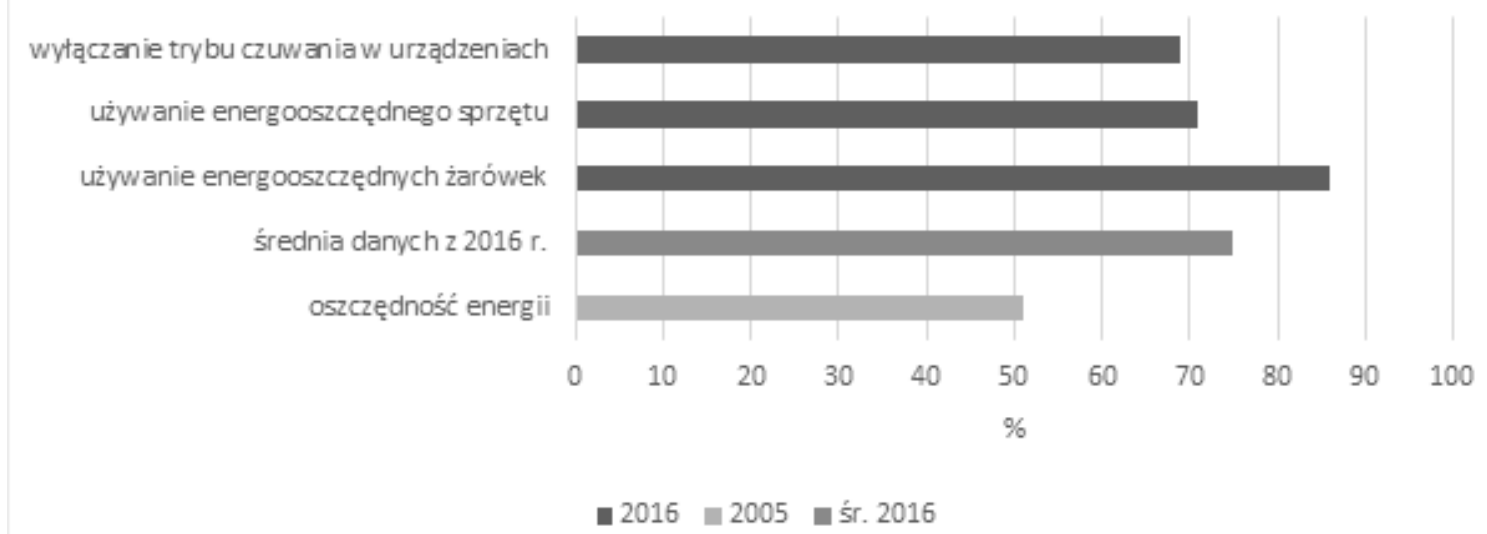

Źródło: badania własne.

Niewiele ponad $40 \%$ respondentów w 2005 roku deklarowało ograniczanie wykorzystywania plastikowych toreb na zakupy. W 2016 roku $72 \%$ studentów wskazało, że zamiast toreb jednorazowych używa toreb wielokrotnego użytku.

W 2005 segregację śmieci deklarowało 32\% badanych, a w 2016 roku - już $76 \%$. Taki duży wzrost prawdopodobnie był wynikiem edukacji szkolnej w tym zakresie, wejścia w życie Ustawy o utrzymaniu czystości i porządku w gminach oraz prowadzonych kampanii informacyjnych związanych z jej wdrażaniem. Zdecydowanie segregowanie śmieci staje się obecnie standardem w zakresie utrzymania czystości w środowisku lokalnym.

Badania porównawcze zmian postaw prośrodowiskowych nie wykazały poprawy, której można było się spodziewać po 11 latach, wydawałoby się intensywnych, działań prośrodowiskowych. Zmalało też znaczenie szkoły w procesie edukacji ekologicznej, a znacząco wzrosła pozycja mediów i innej działalności informacyjnej popularyzującej działania prośrodowiskowe.

Na podstawie badań można stwierdzić, że w zakresie edukacji ekologicznej jest jeszcze dużo do zrobienia. Należy pamiętać, że edukacja ekologiczna i świadomość ekologiczna są tylko początkiem, choć bardzo ważnym, do zmiany postaw i przyzwyczajeń na te przyjazne środowisku. W efekcie określone działania powinny 
stać się nawykiem każdego człowieka i być traktowane jako obowiązkowe w jego codziennym funkcjonowaniu.

Podsumowując przeprowadzone badania, można wyciągnąć następujące wnioski:

- Edukacja ekologiczna powinna być efektywniejsza i prowadzona na każdym szczeblu kształcenia. Przy kolejnej zmianie podstawy programowej dobrym rozwiązaniem byłoby wyodrębnienie treści z zakresu edukacji ekologicznej oraz wskazanie minimalnej liczby godzin na realizację tej tematyki.

- Poprzez proces edukacyjny należy uświadomić młodemu pokoleniu, że każdy indywidualnie może przyczyniać się do poprawy środowiska, wdrażając do swojego postępowania działania wpływające korzystnie na jego stan.

- Obecna edukacja szkolna (zdaniem badanych) nie daje podstaw do ukształtowania postaw prośrodowiskowych.

- Nie są znane podstawowe terminy używane w procesie informacyjnym prowadzonym przez media, takie jak „ekologia” czy „rozwój zrównoważony”, co z pewnością wpływa na niepełne rozumienie przesłań. Tylko $11 \%$ badanych znało termin „rozwój zrównoważony”, termin „ekologia” prawidłowo zdefiniowało 12\% respondentów.

- Wyraźnie widać różnicę w posiadanej wiedzy między studentami, którzy informacje o działaniach proekologicznych czerpali z zajęć obowiązkowych (ścieżki międzyprzedmiotowe), a tymi, którzy skończyli szkołę po reformie. Obecnie treści $\mathrm{z}$ tego zakresu są podawane bardzo skrótowo $\mathrm{w}$ ramach realizacji programu z przyrody i biologii, a przygotowanie do konkursów i projektów dotyczy tylko wybranych, chętnych uczniów. Wskazuje to na konieczność prowadzenia efektywniejszej i obowiązkowej edukacji w tym zakresie.

- Duża część badanych deklaruje podejmowanie działań proekologicznych takich jak: segregacja odpadów, stosowanie toreb wielokrotnego użytku, używanie energooszczędnych żarówek, ograniczenie zużycia wody i gazu. Niestety, to tylko częściowo wskazuje na przyjmowanie przez nich takich postaw na co dzień. Jednak fakt znajomości właściwych zachowań jest krokiem w dobrym kierunku i daje nadzieję na wdrożenie dobrych nawyków do codziennych działań.

\section{Bibliografia}

Cichy D. (2003). Szkoła wobec wyzwań edukacji biologicznej i środowiskowej w XXI wieku. Warszawa: IBE.

Domka L. (1998). Kryzys środowiska a edukacja dla ekorozwoju. Poznań: Wydawnictwo Naukowe UAM.

Ministerstwo Ochrony Środowiska (2008). Polityka ekologiczna państwa w latach 2009-2012 z perspektywa do roku 2016. Warszawa.

www.lider.szs.pl/biblioteka/download.php?plik_id=139o\&f=artykul_139o.doc (otwarty 1.05.2016). 


\title{
THE ROLE OF PRO-ECOLOGICAL ACTIVITIES IN SHAPING THE ECOLOGICAL AWARENESS
}

\begin{abstract}
The level of environmental protection awareness among students is not sufficient. Although the research was carried out at an interval of 11 years, the state of awareness has not changed to the extent expected, and, in some areas, the studies show a decrease in taking environmental action. Raising the level of environmental awareness and shaping attitudes is only possible in the course of environmental education and comprehensive information on the condition and needs of the environment and the pro-environmental activities being taken in the immediate and more distant environment. Students' level of knowledge shows the need to take immediate actions which influence the information resource as a base to start shaping pro-environmental awareness. Ecologically aware individual will be undertaking in daily life environmentally friendly activities and will be making choices that are not harmful for the environment. The fact of deterioration of results indicates the need for intensive environmental education and verification of the effectiveness of various institutions in this respect.
\end{abstract}

Keywords: pro-ecological awareness, environmental education

Anna Strumińska-Doktór - doktor nauk humanistycznych w zakresie pedagogiki, nauczyciel akademicki - starszy wykładowca NWSP w Białymstoku oraz na uczelniach warszawskich, nauczyciel dyplomowany, wieloletnia nauczycielka i dyrektorka szkoły podstawowej. Rzeczoznawca MEN do spraw podręczników w zakresie geografii; wielokrotna egzaminatorka OKE; ekspert MEN ds. awansu zawodowego. Wielokrotna laureatka nagród, m.in. MEN, KEN, Prezydenta Warszawy. Zajmuje się tematyką związaną z pedagogiką wczesnoszkolną, andragogiką i pedeutologią, edukacją ekologiczną i zarządzaniem oświatą. Jest autorką wielu artykułów z tego zakresu. Bierze aktywny udział w konferencjach naukowych, projektach europejskich na rzecz społeczności lokalnych. Ostatnie publikacje: Patologie społeczne... (2014), Jak skutecznie wypromować szkołę i placówkę oświatowa (2015). Adres e-mail: anisd@wp.pl. 